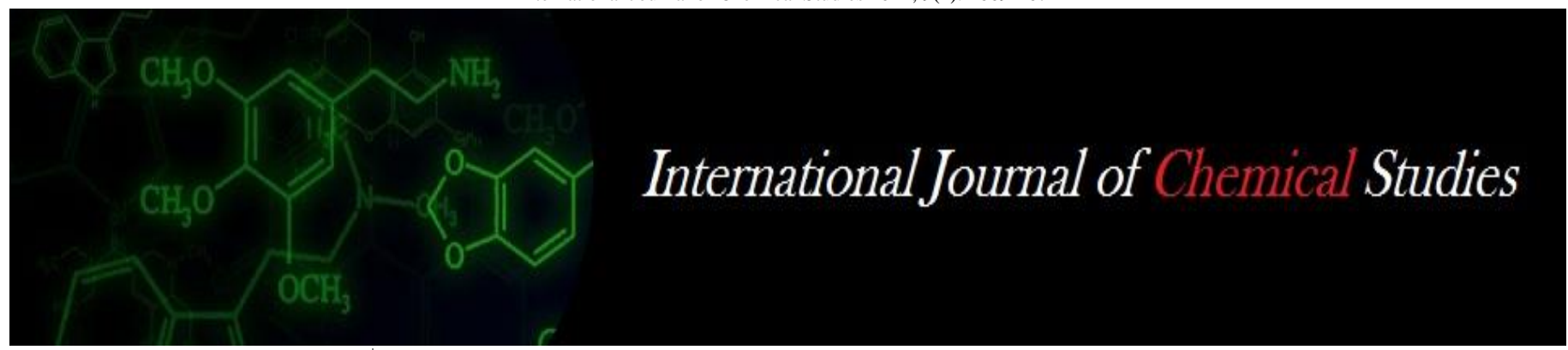

P-ISSN: 2349-8528

E-ISSN: 2321-4902

www.chemijournal.com

IJCS 2021; 9(1): 1669-1674

(C) 2021 IJCS

Received: 05-10-2020

Accepted: 13-11-2020

\section{Mitkal KT}

Department of Food Science and Technology, Post Graduate

Institute Mahatma Phule Krishi

Vidyapeeth, Rahuri

Maharashtra, India

\section{Kotecha PM}

Department of Food Science and Technology, Post Graduate

Institute Mahatma Phule Krishi

Vidyapeeth, Rahuri

Maharashtra, India

\section{Godase SN}

Department of Food Science and Technology, Post Graduate

Institute Mahatma Phule Krishi

Vidyapeeth, Rahuri

Maharashtra, India

\section{UD Chavan}

Department of Food Science and Technology, Post Graduate

Institute Mahatma Phule Krishi

Vidyapeeth, Rahuri

Maharashtra, India

\section{Corresponding Author:}

\section{Mitkal KT}

Department of Food Science and Technology, Post Graduate Institute Mahatma Phule Krishi Vidyapeeth, Rahuri

Maharashtra, India

\section{Studies on nutritional quality of Kodo millet cookies}

\section{Mitkal KT, Kotecha PM, Godase SN and UD Chavan}

\author{
DOI: https://doi.org/10.22271/chemi.2021.v9.i1x.11465
}

\begin{abstract}
The quality cookies were prepared from $50 \%$ maida and 50\% kodo millet flour $\left(\mathrm{CMKF}_{50}\right)$. The selected treatments were packed in LDPE and PP and stored at ambient $\left(30 \pm 4{ }^{0} \mathrm{C}\right)$ for 90 days to study their storage feasibility. Chemical composition of the fresh cookies prepared from $50 \%$ maida and $50 \%$ kodo millet flour $\left(\mathrm{CMKF}_{50}\right)$ showed that moisture content was $4.11 \%$, protein $10.20 \%$, crude fat $25.70 \%$, crude fiber $4.40 \%$, carbohydrates $69.87 \%$, calcium $25.03 \mathrm{mg} / 100 \mathrm{~g}$, and iron $2.20 \mathrm{mg} / 100 \mathrm{~g}$. The sensory evaluation of cookies was carried out regularly at an interval of one month for 3 month during storage. The results on overall acceptability score of cookies are influenced by storage. The results indicated that score for overall acceptability of cookies was decreased for control from7.30 to 7.10 in LDPE and from 7.20 to 6.90 in $\mathrm{PP}$ as storage period get increased. For $\mathrm{CMKF}_{50}$ treatment score decreased from 7.40 to 7.15 in LDPE and 7.30 to 7.10 in PP was observed for 90 days of storage. Storage study of cookies showed that the cookies prepared by incorporation of maida and kodo millet flour can be stored up to 3 month in LDPE with minimum losses in sensory, nutritional and textural characteristics than PP. There was no significant difference in protein, crude fiber, calcium and iron content with advancement of storage period during 3 month. The cookies were found to be acceptable up to 3 month storage at ambient temperature. The total cost of production of cookies prepared from maida and kodo millet flour $\left(\mathrm{CMKF}_{50}\right)$ for $1 \mathrm{~kg}$ was Rs. 122/-.
\end{abstract}

Keywords: Kodo millet, cookies, nutritional value, organoleptic properties

\section{Introduction}

The demand for processed foods is ever increasing due to the technological, industrial and economic advances of the developing societies of the world including India. The bakery industry has been steadily growing in the country, being the largest among the processed food industries. The two major bakery industries namely bread and biscuits account for almost 82 per cent of the total bakery products. The annual production of bakery products is estimated to be more than 3.0 million tonnes (www.biscuitfederation.org). India is recognized to be the second largest producer of biscuits next only to the United States of America with annual production of which was 7.40 lakh metric tonnes in 1997-98 which has escalated to 17.14 lakh metric tonnes in 2005-2009 (Agrawal, 1990) ${ }^{[3]}$. Among the bakery products biscuits command wide popularity in rural as well as urban areas among people of all age groups (Agrawal, 1990) ${ }^{[3]}$. The production of biscuits in the country, both in the organized and unorganized sectors, is estimated to be around 11 million tones.

The cookie formula consists of refined flour, hydrogenated fat, sugar and other additives. It is well documented that most of the ingredients used in commercial cookies lack important nutrients. The refined flour lacks in dietary fiber and micronutrients which are important health promoting components. The hydrogenated fat comprises of trans-fats which have proven to be harmful to human health. Recognizing the negative health effects of transfats many countries have banned the trans-fats in foods and have recommended zero tolerance to trans-fats in foods for infants and other vulnerable groups. Nutrition labeling to indicate the trans-fats content is made mandatory in many countries.

There is a growing awareness among the consumers regarding the constituents that affect health both positively and negatively. The number of such health conscious consumers is fast increasing and so is the health food industry. New foods with new health claims are flooding the market to meet the diverse demands of consumers. 
However, still there is ample scope to enhance the nutritional value of cookies both quantitatively and qualitatively using nutritious food ingredients. In this regard, there are several food ingredients with exceptional nutritional qualities because of their nutraceutical and /or nutritional components, such as millets, oil seeds, condiments and other novel ingredients. Value addition to existing foods with such ingredients is a simple and feasible way of enhancing nutritional values of foods and in turn the health benefits.

Millets have been in food use since time immemorial and an array of traditional foods are prepared across rural India. However, food use of millets is fast decreasing due to several reasons. There is therefore a need to revive these important groups of health promoting foods to enhance nutritional quality of diets of consumers. Among the millets kodo millet (paspalum scrobiculatum) is an important underutilized grain, also called as kodara, varagu, haraka, arakalu, and Japanese kodo millet. It forms the main stay of the dietary nutritional requirements. It has high protein content (11\%), low fat $(4.2 \%)$ and very high fibre content $(14.3 \%)$. Kodo millet is very easy to digest, it contains a high amount lecithin and is excellent for strengthening the nervous system. Kodo millet are rich in vitamins B, specially niacin, B6 and folic acid, as well as the mineral such as calcium, iron. Kodo millet contain no gluten and is good for people who are gluten intolerant. Regular consumption of kodo millet is very beneficial for postmenopausal women suffering from signs of cardiovascular disease, like high blood pressure and high cholesterol level.

Additionally, it can blend with most of traditional and novel foods without imparting any flavours of its own. Hence, in the present study kodo millet was chosen to enhance the nutrient composition of cookies and biscuits in terms of dietary fiber and other nutrients

\section{Materials and Methods \\ Materials}

Ingredients: The major ingredients for the preparation of products were kodo millet procured from Zonal Agriculture Research Station, Kolhapur. The maida was procured from local market.

Packaging material: The packaging material viz., LDPE and PP bags were procured from local market and used for packaging of cookies for storage study.

Treatment details: The kodo millet cookies were prepared by using different levels of kodo millet flour with maida as shown below:

Table 1: Treatment details for preparation of kodo millet cookies

\begin{tabular}{|c|c|c|}
\hline Treatments & Maida (\%) & Kodo millet flour (\%) \\
\hline $\mathrm{T}_{0}($ Control) & 100 & 0 \\
\hline $\mathrm{T}_{1}$ & 90 & 10 \\
\hline $\mathrm{T}_{2}$ & 80 & 20 \\
\hline $\mathrm{T}_{3}$ & 70 & 30 \\
\hline $\mathrm{T}_{4}$ & 60 & 40 \\
\hline $\mathrm{T}_{5}$ & 50 & 50 \\
\hline $\mathrm{T}_{6}$ & 40 & 60 \\
\hline $\mathrm{T}_{7}$ & 30 & 70 \\
\hline $\mathrm{T}_{8}$ & 20 & 80 \\
\hline $\mathrm{T}_{9}$ & 10 & 90 \\
\hline $\mathrm{T}_{10}$ & 0 & 100 \\
\hline
\end{tabular}

\section{Method}

Procedure for preparation of kodo millet flour

The kodo millet grains were cleaned to remove extraneous matter and taken in small bowel and then attached to the electric decorticator to remove brans. The dried debraned kodo millet grains were grinded in to flour and passed through sieve of 80 mesh to get uniform flour.

\section{Preparation of kodo millet flour cookies}

The cookies were prepared using standard levels of ingredients as per the traditional creaming process.
Hydrogenated vegetable fat and powdered sugar mixed thoroughly

$$
\downarrow
$$

Wheat flour + Barnyard millet flour + Sodium bicarbonate + ammonium bicarbonate

$$
\downarrow
$$

Mix both the blends

$\downarrow$

The dough will framed into a sheet and cut with impression cutter

$\downarrow$

Kept for 2-3 $\mathrm{min}$

$\downarrow$
Baking at $180{ }^{\circ} \mathrm{C}$ for 12 minute
$\downarrow$
Cooling and Packaging
$\downarrow$
Storage

Fig 1: Flow chart for preparation of kodo millet cookies

\section{Physical characteristics of raw material}

The raw material kodo millet grains were analyzed for different physical characteristics like thousand kernel weight, bulk density and colour.

\section{Chemical properties of raw materials and cookies}

Chemical constituents like moisture, fat, protein, carbohydrate, crude fiber and minerals like calcium, phosphorous and iron content of raw material and cookies were determined as per the standard procedure.

\section{Physico-chemical analysis of raw material cookies}

The method described in A.O.A.C. $(2000)^{[1,2]}$ for determining moisture was used. The protein content of cookies was estimated by determining total nitrogen content using standard Micro-Kjeldhal method and fat content of the cookies was estimated by the soxhlet method A.A.C.C (2000) $[1,2]$. The crude fiber content in the products was estimated by A.A.A.C. (2000) ${ }^{[1]}$. The carbohydrate content in the selected cookies were obtained by subtracting from 100, the sum of values of moisture, protein and fat content per $100 \mathrm{~g}$ of the sample (Raghuramulu, et al., 1993) ${ }^{[20]}$. Calcium, phosphorous and iron were analyzed using atomic absorption spectrometry (AAS). These methods give a good precision and accuracy (Ojeka and Ayodele 1995.) ${ }^{[18]}$

\section{Packaging and storage of kodo millet cookies}

The selected treatments of kodo millet cookies were packed in LDPE and PP and stored at ambient $\left(30+4^{\circ} \mathrm{C}\right)$ for 3 months. The samples were drawn at an interval of 1 month and evaluated for chemical and sensory quality. 


\section{Sensory evaluation of cookies}

Sensory evaluation of kodo millet cookies was carried on 9 point hedonic scale. The average scores of the ten judges for different quality characteristics viz. colour and appearance, flavour, texture, taste and overall acceptability were recorded.

\section{Statistical analysis}

All experiments were carried out by using Factorial Completely Randomized Design (FCRD). The results obtained in the present investigation were analyzed for the statistical significance according to the procedure given by Rangaswamy (2010) ${ }^{[21]}$.

\section{Results and Discussion}

\section{Physical characteristics of raw materials}

The results obtained for physical characteristics of kodo millet grains are presented below:

Table 2: Physical characteristics of raw materials

\begin{tabular}{|c|c|}
\hline Parameter & Kodo millet \\
\hline Colour & Creamish white \\
\hline 1000 Grain Weight $(\mathrm{g})$ & 71.20 \\
\hline Bulk density $(\mathrm{g} / \mathrm{ml})$ & 650 \\
\hline True density $(\mathrm{g} / \mathrm{ml})$ & 1172 \\
\hline Porosity $(\%)$ & 39.68 \\
\hline Angle of repose & $21^{0}$ \\
\hline
\end{tabular}

The seed colour was creamish white which indicated good quality. Bulk density of seeds was found to be $650 \mathrm{~g} / \mathrm{ml}$. The variations in density of kodo millet may be due to random harvesting of kodo millet at different maturity stages. This factor is important because it determines the capacity of storage, packaging and transport systems. The weight of 1000 grains is $71.20 \mathrm{~g}$. The shape of grain and rice are spheroid.

\section{Chemical characters of raw materials}

The results obtained for chemical characteristics of maida and kodo millet flour are presented here:

Table 3: Chemical characters of raw materials

\begin{tabular}{|c|c|c|}
\hline Chemical constituent & Maida & Kodo millet flour \\
\hline Moisture (\%) & 13.3 & 10.90 \\
\hline Protein (\%) & 11 & 8.30 \\
\hline Fat (\%) & 0.9 & 1.30 \\
\hline Crude fiber (\%) & 0.3 & 8.50 \\
\hline Carbohydrates (\%) & 73.9 & 65.90 \\
\hline Calcium (mg/100g) & 23 & 27.00 \\
\hline Iron (mg/100g) & 2.7 & 1.70 \\
\hline
\end{tabular}

*Each value is the average of three determinations
Chemical characters of various raw materials are comparable with findings reported by o Tosco, (2004) ${ }^{[30]}$ Gopalan, et al., (2006) ${ }^{[11]}$. Similar conclusions have been drawn by Bushway, et al., (1981) ${ }^{[8]}$, Mayela, et al., (2007) ${ }^{[15]}$ and Salazar, et al., $(2011)^{[24]}$

\section{Sensory evaluations of fresh kodo millet cookies}

The organoleptic evaluation of cookies prepared by different combination of kodo millet flour and maida were carried out. Kodo millet cookies were prepared and presented to panel of ten judge for assessing the quality and acceptability of product. Organoleptic evaluation of cookies was carried out using a 9 point hedonic scale of sensory characteristics such as colour, flavour texture, taste and overall acceptability. The score obtained for sensory evaluation for maida and kodo millet flour cookies are shown in Table 4. Maida and kodo millet cookies (50 maida: 50 kodo millet flour) were found the best for preparation of cookies and stored at ambient temperature $\left(30 \pm 4^{\circ} \mathrm{C}\right)$ for 3 month.

Organoleptic quality parameters of a product assume pivotal role in anticipating the consumer response to the product (Rey 2006) [23]. Colour and appearance uniformity are vital components of visual quality of fresh as well as processed foods and play a major role in consumer choice (Alistair $2005)^{[4]}$. Flavour being a combination of taste, smell and mouth feel, has multifaceted impact on sensory quality of a product (Amerine, et al., 1980) ${ }^{[5]}$. Overall acceptability of product is a function of various factors including colour and appearance, flavour, texture and taste. Amongst all samples for both cookies containing maida 50 per cent and kodo millet 50 per cent combination was found to be more acceptable. Singh et al., (2000) [28] reported overall acceptability of product like cookies is a function of various factors including colour and appearance, flavour, texture and taste in the soy fortified biscuits storage. Gupta and Singh (2005) ${ }^{[12]}$ reported overall acceptability of biscuits containing colour and appearance, flavour, texture and taste which gives overall acceptance by considering above all attributes.

\section{Selection of Best Combination for Preparation of Kodo Millet Fortified Cookies}

On the basis of organoleptic properties (colour and appearance, flavour, texture, taste and overall acceptability) the best combination from maida and kodo millet flour was 50:50. For the storage study these combinations with control (100\% maida) were selected and the cookies prepared from them were used for further storage study. During storage study their nutritional composition, organoleptic properties and microbial quality were analysed using standard procedures.

Table 4: Sensory evaluation of fresh Maida and kodo millet flour cookies*

\begin{tabular}{|c|c|c|c|c|c|c|}
\hline \multirow{2}{*}{ Sample code } & \multicolumn{6}{|c|}{ Sensory attributes* } \\
\hline & Colour and appearance & Flavour & Texture & Taste & Overall acceptability & Rank \\
\hline $\mathrm{CMKF}_{0}$ & 8.3 & 7.8 & 8.0 & 7.1 & 7.80 & 6 \\
\hline $\mathrm{CMKF}_{10}$ & 8.0 & 7.6 & 7.5 & 8.1 & 7.81 & 5 \\
\hline $\mathrm{CMKF}_{20}$ & 7.6 & 7.3 & 7.6 & 8.0 & 7.82 & 4 \\
\hline $\mathrm{CMKF}_{30}$ & 8.0 & 8.0 & 7.6 & 8.3 & 7.90 & 3 \\
\hline $\mathrm{CMKF}_{40}$ & 8.0 & 8.0 & 7.8 & 8.3 & 8.02 & 2 \\
\hline $\mathrm{CMKF}_{50}$ & 8.8 & 8.5 & 9.0 & 9.0 & 8.82 & 1 \\
\hline $\mathrm{CMKF}_{60}$ & 6.8 & 7.3 & 6.5 & 7.3 & 6.90 & 7 \\
\hline $\mathrm{CMKF}_{70}$ & 6.5 & 7.0 & 6.5 & 7.3 & 6.80 & 8 \\
\hline $\mathrm{CMKF}_{80}$ & 6.5 & 7.0 & 6.3 & 7.3 & 6.77 & 9 \\
\hline $\mathrm{CMKF}_{90}$ & 6.3 & 7.0 & 6.3 & 7.3 & 6.72 & 10 \\
\hline $\mathrm{CMKF}_{100}$ & 6.5 & 6.5 & 6.5 & 6.5 & 6.50 & 11 \\
\hline
\end{tabular}




\begin{tabular}{|c|c|c|c|c|c|}
\hline Mean & 7.390 & 7.454 & 7.236 & 7.681 & - \\
\hline S.E.土 & 0.039 & 0.057 & 0.247 & 0.057 & -4.441 \\
\hline C.D at 5\% & 0.114 & 0.169 & 0.724 & 0.039 & 0.169 \\
\hline
\end{tabular}

*Maximum score out of 9 . All results are mean value of ten determinations.

where as,

CMKF0: (100 maida: 0 kodo millet flour),

$\mathrm{CMKF}_{20}$ : (80 maida: 20 kodo millet flour),

$\mathrm{CMKF}_{40}$ : (60 maida: 40 kodo millet flour),

$\mathrm{CMKF}_{60}$ : (40 maida: 60 kodo millet flour),

$\mathrm{CMKF}_{80}$ : (20 maida: 80 kodo millet flour),

$\mathrm{CMKF}_{100}$ : (0 maida: 100 kodo millet flour).
CMKF 10: (90 maida: 10 kodo millet flour),

$\mathrm{CMKF}_{30}$ : (70 maida: 30 kodo millet flour),

CMKF50: (50 maida: 50 kodo millet flour),

$\mathrm{CMKF}_{70}$ : (30 maida: 70 kodo millet flour),

CMKF90: (10 maida: 90 kodo millet flour),
Nutritional value changes in kodo millet cookies during storage: The average values of fresh cookies (100\% maida) was moisture increased for treatment $\mathrm{CMKF}_{0}$ from 4.13 to 4.18 per cent in LDPE and 4.15 to 4.23 per cent in PP was observed for 90 days of the storage. The sample $\mathrm{CMKF}_{50}$ showed increase in the moisture content 4.07 to 4.15 per cent in LDPE and 4.09 to 4.17 per cent in PP. Protein decreased for $\mathrm{CMKF}_{0}$ treatment from 12.05 to 11.99 per cent in LDPE and from 12.03 to 11.91 per cent in PP was observed for 90 days of storage. The sample $\mathrm{CMKF}_{50}$ showed from 10.15 to 10.04 per cent in LDPE and from 10.13 to 10.02 per cent in PP. Fat decreased for treatment $\mathrm{CMKF}_{0}$ from 25.87 to 25.78 per cent in LDPE and from 25.85 to 25.76 per cent in PP was observed for 90 days of storage. The sample $\mathrm{CMKF}_{50}$ showed from 26.11 to 26.03 in LDPE and from 26.09 to 26.01 in PP. Crude fiber decreased for treatment $\mathrm{CMKF}_{0}$ from 0.27 to 0.20 per cent in LDPE and from 0.25 to 0.19 per cent in PP was observed for 90 days of storage. The sample $\mathrm{CMKF}_{50}$ showed crude fibre content 4.35 to 4.26 per cent in LDPE and from
4.32 to 4.24 per cent in PP. Carbohydrates decreased for $\mathrm{CMKF}_{0}$ from 73.88 to 73.83 per cent LDPE and from 73.86 to 73.78 per cent in PP was observed for 90 days of storage. The sample $\mathrm{CMKF}_{50}$ showed carbohydrate content 69.84 to 69.77 per cent in LDPE and from 69.81 to 69.75 per cent in PP. Calcium decreased for treatment $\mathrm{CMKF}_{0}$ from 22.96 to 22.89 $\mathrm{mg} / 100 \mathrm{~g}$ in LDPE and from 22.93 to $22.86 \mathrm{mg} / 100 \mathrm{~g}$ in PP was observed for 90 days. The sample $\mathrm{CMKF}_{50}$ showed from 24.98 to $24.91 \mathrm{mg} / 100 \mathrm{~g}$ in LDPE and from 24.95 to 22.89 $\mathrm{mg} / 100 \mathrm{~g}$ in PP. Iron decreased for treatment $\mathrm{CMKF}_{0}$ from 2.68 to $2.61 \mathrm{mg} / 100 \mathrm{~g}$ in LDPE and 2.66 to $2.59 \mathrm{mg} / 100 \mathrm{~g}$ in $\mathrm{PP}$ was observed for 90 days. The sample $\mathrm{CMKF}_{50}$ showed from 2.17 to $2.11 \mathrm{mg} / 100 \mathrm{~g}$ in LDPE and from 2.15 to 2.08 $\mathrm{mg} / 100 \mathrm{~g}$ in PP (Table 7). Protein, fat, crude fiber, carbohydrate, calcium and iron decreased in ambient temperature during storage period of 3 month. The decrease in moisture, protein, fat, carbohydrate, crude fiber, calcium and iron was more rapid in the samples stored in PP than LDPE during the storage period.

Table 5: Nutritional changes in kodo millet cookies during storage at ambient temperature

\begin{tabular}{|c|c|c|c|c|c|c|c|}
\hline Parameter & Moisture (\% & Protein (\%) & Fat $(\%)$ & Crude fiber (\%) & Carbohydrate (\%) & Calcium (mg/100 g) & Iron $(\mathrm{mg} / \mathrm{100} \mathrm{g})$ \\
\hline \multicolumn{8}{|l|}{ Treatment } \\
\hline $\mathrm{T}_{0}: \mathrm{CMKF}_{0}$ & 4.16 & 11.99 & 25.81 & 0.23 & 73.84 & 22.91 & 2.63 \\
\hline $\mathrm{T}_{1}: \mathrm{CMKF}_{50}$ & 4.11 & 10.08 & 26.05 & 4.30 & 69.79 & 24.93 & 2.12 \\
\hline S.E. + & 0.002 & 0.003 & 0.002 & 0.001 & 0.002 & 0.002 & 0.002 \\
\hline $\mathrm{CD}$ at $5 \%$ & 0.007 & 0.008 & 0.007 & 0.004 & 0.007 & 0.007 & 0.007 \\
\hline \multicolumn{8}{|l|}{ Packaging material } \\
\hline $\mathrm{P}_{1}$ : Low Density Polyethylene & 4.12 & 11.05 & 25.94 & 2.27 & 71.83 & 23.93 & 2.39 \\
\hline $\mathrm{P}_{2}$ : Polypropylene & 4.16 & 11.01 & 25.92 & 2.25 & 71.80 & 23.91 & 2.37 \\
\hline S.E. + & 0.002 & 0.003 & 0.002 & 0.001 & 0.002 & 0.002 & 0.002 \\
\hline $\mathrm{CD}$ at $5 \%$ & 0.007 & 0.008 & 0.007 & 0.004 & 0.007 & 0.007 & 0.007 \\
\hline \multicolumn{8}{|l|}{ Storage period } \\
\hline $\mathrm{C}_{1}: 30$ days & 4.11 & 11.09 & 25.98 & 2.30 & 71.84 & 23.95 & 2.41 \\
\hline $\mathrm{C}_{2}: 60$ days & 4.14 & 11.03 & 25.93 & 2.26 & 71.82 & 23.92 & 2.38 \\
\hline $\mathrm{C}_{3}$ : 90 days & 4.16 & 10.99 & 25.89 & 2.22 & 71.78 & 23.88 & 2.34 \\
\hline S.E. + & 0.003 & 0.003 & 0.003 & 0.002 & 0.003 & 0.003 & 0.003 \\
\hline $\mathrm{CD}$ at $5 \%$ & 0.008 & 0.009 & 0.008 & 0.005 & 0.008 & 0.008 & 0.008 \\
\hline \multicolumn{8}{|l|}{ Interaction } \\
\hline $\mathrm{T}_{0} \mathrm{P}_{0} \mathrm{C}_{1}$ & 4.13 & 12.05 & 25.87 & 0.27 & 73.88 & 22.96 & 2.68 \\
\hline $\mathrm{T}_{0} \mathrm{P}_{0} \mathrm{C}_{2}$ & 4.16 & 12.02 & 25.83 & 0.24 & 73.85 & 22.93 & 2.65 \\
\hline $\mathrm{T}_{0} \mathrm{P}_{0} \mathrm{C}_{3}$ & 4.18 & 11.99 & 25.78 & 0.20 & 73.83 & 22.89 & 2.61 \\
\hline $\mathrm{T}_{0} \mathrm{P}_{1} \mathrm{C}_{1}$ & 4.15 & 12.03 & 25.85 & 0.25 & 73.86 & 22.93 & 2.66 \\
\hline $\mathrm{T}_{0} \mathrm{P}_{1} \mathrm{C}_{2}$ & 4.19 & 11.96 & 25.80 & 0.21 & 73.84 & 22.91 & 2.62 \\
\hline $\mathrm{T}_{0} \mathrm{P}_{1} \mathrm{C}_{3}$ & 4.23 & 11.91 & 25.76 & 0.19 & 73.78 & 22.86 & 2.59 \\
\hline $\mathrm{T}_{1} \mathrm{P}_{0} \mathrm{C}_{1}$ & 4.07 & 10.15 & 26.11 & 4.35 & 69.84 & 24.98 & 2.17 \\
\hline $\mathrm{T}_{1} \mathrm{P}_{0} \mathrm{C}_{2}$ & 4.10 & 10.09 & 26.07 & 4.31 & 69.81 & 24.95 & 2.14 \\
\hline $\mathrm{T}_{1} \mathrm{P}_{0} \mathrm{C}_{3}$ & 4.15 & 10.04 & 26.03 & 4.26 & 69.77 & 24.91 & 2.11 \\
\hline $\mathrm{T}_{1} \mathrm{P}_{1} \mathrm{C}_{1}$ & 4.09 & 10.13 & 26.09 & 4.32 & 69.81 & 24.95 & 2.15 \\
\hline $\mathrm{T}_{1} \mathrm{P}_{1} \mathrm{C}_{2}$ & 4.13 & 10.05 & 26.04 & 4.29 & 69.78 & 24.92 & 2.12 \\
\hline $\mathrm{T}_{1} \mathrm{P}_{1} \mathrm{C}_{3}$ & 4.17 & 10.02 & 26.01 & 4.24 & 69.75 & 24.89 & 2.08 \\
\hline S.E. + & 0.006 & 0.006 & 0.006 & 0.003 & 0.006 & 0.006 & 0.006 \\
\hline $\mathrm{CD}$ at $5 \%$ & 0.017 & 0.019 & NS & NS & 0.017 & NS & NS \\
\hline
\end{tabular}

Parameter

Where, $\mathrm{CMKF}_{0}$ : Cookies with $100 \%$ maida and $0 \%$ kodo millet flour.

$\mathrm{CMKF}_{50}$ : Cookies with $50 \%$ maida and $50 \%$ kodo millet flour. 
Mirsaeedghazi, et al., (2008) ${ }^{[16]}$ reported that increase of protein in dough causes greater consistency of dough. The interaction including physical and chemical forces among protein molecules play key role on the rheological properties (Shiau and Yeh, 2001) ${ }^{[27]}$. The increase in protein content is acceptable for better rheological characteristics.

In cookies production, addition of fat imparts tenderness making it more palatable; assist in texture improvements. External added fat during preparation of cookies have plasticizing effects reported by Mulvancey and Cohen (1997) [17].

Sharoon, et al., (2014) ${ }^{[26]}$ reported considerable increment the moisture content in all cookies with increasing storage duration. This increase was primarily due to packaging material (polythene bags). Sujitha and Thirumani (2014) [29] also reported increase in moisture content from 3.6-5.6\% of flaxseed cookies during the storage period of 60 days. This increase was primarily due to packaging material (polythene bags). The packaging was not airtight and lack of temperature control resulted in an increase in moisture contents of cookies. Moreover, cookies absorbed moisture from surrounding atmosphere due to hygroscopic behavior of wheat flour. An increase in moisture contents of cookie samples during storage has also been reported by Leelavathi and Rao (1993) ${ }^{[14]}$, Rao, et al., (1995) ${ }^{[22]}$ Pasha, et al., (2002) ${ }^{[19]}$, Butt, et al., (2004) [9] and Shariff, et al., (2005) [25] either due to atmosphere or packaging materials.

\section{Conclusion}

These results indicates that $\mathrm{CMKF}_{50}$ cookies (50 per cent maida and 50 per cent kodo millet flour) with constant levels of other ingredients viz. sugar $50 \mathrm{~g}$, vanspati ghee $50 \mathrm{~g}$,sodium bicarbonate $1 \mathrm{~g}$,ammonium bicarbonate $1 \mathrm{~g}$ and water $20 \mathrm{ml}$ respectively. Stored at ambient temperature had better acceptability till $90^{\text {th }}$ day. It is evident from all the physicochemical properties that $\mathrm{CMKF}_{50}$ cookies (50 per cent maida and 50 per cent kodo millet flour are the best in LDPE than PP for preparation of kodo millet cookies of good quality.

\section{References}

1. ACC. Official Methods of Analysis of AACC International, American Association of Cereal Chemists, Washington D.C 2000.

2. OAC. Offical Methods of Analyasis, 18th edition. Association of Official Analytical Chemist. Washignton DC 2000, 454.

3. Agrawal SR. Prospects for small-scale biscuit industry in the nineties. Indian Food Indus 1990;9:19-21.

4. Alistair SG. Postharvest Handling and Preparation of Foods for Processing. In Food Processing Handbook. Edited by James G.B. Wiley-VCH Verlag GmbH and Co. KGaA, Weinheim 2005, 87.

5. Amerine MA, Pangborn RM, Roessler EB. Principles of Sensory Evaluation of Food. Academic Press. New York $1980,549$.

6. Anonymous. Annual Report of All India Coordinated Research Project, ICAR, New Delhi 2009.

7. Barbosa GV, Juliano P, Peleg M. Engineering Properties of Foods, in Food Engineering, (Ed. Gustavo V. BarbosaCánovas), in Encyclopedia of Life Support Systems (EOLSS), Developed under the Auspices of the UNESCO, Eolss Publishers, Oxford, UK 2006, 22.

8. Bushway AA, Belyea PR, Bushway RJ. Foxtail millet as a source of oil, polysaccharide, and protein. Journal of Food Science 1981;46:1349-1350.
9. Butt MS, Sharif K, Mukhtar T, Rasool J. Storage studies of red palm oil fortified cookies. Nutr. Food Sci 2004;34(6):272-76.

10. Coskuner Y, Karababa E. Physical properties of coriander seeds (Coriandrum sativum) Journal of Food Engineering 2007;80:408-416.

11. Gopalan C, Ramashastri BV, Balasubramanium SC. Nutritive Value of Indian Foods. National Institute of Nutrition, ICMR, Hyderabad 2006, 47-69.

12. Gupta HO, Singh NN. Preparation of wheat and quality protein maize based biscuit and their storage, protein quality and sensory evaluation. J Food Sci. Technol 2005;42(1):43-46.

13. James GB. Food Processing Handbook. Edited by James G.B. Wiley-VCH Verlag $\mathrm{GmbH}$ and Co. KGaA, Weinheim 2005, 27.

14. Leelavathi K, Rao PH. Development of high fiber biscuits using wheat bran: Journal of Food Science Technology 1993;30(3):187-90.

15. Mayela BJ, Denisse AC, Ernesto AC, Katarzyna W, Kazimierz W, Guadalupe AG et al. Bread development with soybean, chia, linseed, and folic acid as a functional food for woman. Archivos Latino americanos De Nutricion 2007;57(1):78-84.

16. Mirasaeedghazi H, Emam-Djomeh Z, Mousavi SA. Rheometric measurement of dough rheological characteristics and Factor affecting it. Int. J Agri. Bio 2008;10:112-119.

17. Mulvancey F, Cohen C. Effect of added fat on the rheological properties of wheat flour dough. Cereal Chem 1997;74(2):304-11.

18. Ojeka EO, Ayodele JT. Determination of chromium, copper, lead and nickel in some Nigerian vegetables oils. Spectrum 1995;2:75-78.

19. Pasha I, Butt MS, Anjum FM, Shehzadi N. Effect of dietetic sweeteners on the quality of cookies. International Journal of Agriculture and Biology 2002;4(2):245-248.

20. Raghuramulu N, Nair MK, Kalyanasundaram S. A Manual of Laboratory Technique, National Institute of Nutrition, Indian Council of Medical Research, Hyderabad, India 1993, 69-72.

21. Rangaswamy R. A Text Book of Agricultural Statistics, Second edition and New Age International Publishers. New Delhi 2010, 234-458.

22. Rao TS, Rajmanuja MN, Ashok N, Vaibhaker HS. Storage properties of whole egg powder incorporated biscuits. J Food Sci. Tech 1995;32(6):470-76.

23. Rey CE, Tecantea A, Valdivia MA. Dietary fibre content and antioxidant activity of phenolic compounds present in Mexican foxtail millet (Setaria italica L.) seeds. Food Chemistry 2006;107(2):656-663.

24. Salazar VM, Maira R, Segura C, Luis A, Chel G, David A. Antihypertensive and antioxidant effects of functional foods containing foxtail millet (Setaria italica) Protein Hydrolysates. Scientific, Health and Social Aspects of the Food Industry 2011, 382-398.

25. Shariff M, Butt M, Huma N. Oil extraction from rice industrial waste and its effect on physic-logical characteristics of cookies. Nutr. Food Sci 2005;35(6):416-27.

26. Sharoon M, Zafar I, Atta M, Arif M, Rafiq G, Anjum R. Effect of linseed oil substituation on physic-chemical properties of cookies. J Agric. Res 2014;52(3):425-437. 
27. Shiau SY, Yeh A. Effect of alkali and acid on dough rheological properties and Characteristics of extruded noodles. J Cereal Sci 2001;33:27-37.

28. Singh R, Singh G, Chauhan GS. Nutritional evaluation of soy fortified biscuits. Journal of Food Science Technology 2000;37(2):162-164.

29. Sujitha R, Thirumani D. Physicochemical and sensory characteristics of value added breakfast biscuits. Int. J Adv. Res 2014;2(3):556-563.

30. Tosco G. Los beneficios de la chía en humanos y animales. Nutrimentos de la semilla de chíay surelación con los requerimientos humanos diarios. Actualidades Ornitológicas 2004;119:1-70.

31. Ugare R. Health benefits, storage quality and value addition of barnyard millet (Echinochloa frumentacaea L.) M. H. Sc. Thesis, Univ. Agric. Sci., Dharwad (India) 2008.

32. Vanesa Y, Susana M, Mabel C. Physical properties of foxtail millet (Setaria italica.) seeds. Industrial Crops and Products 2008;28(3):286-293.

33. Veena B, Chimmad BV, Naik RK, Shantakumar G. Physico-chemical and nutritional studies in barnyard millet. Karnataka J Agric. Sci 2005;18(1):101-105.

34. Vilche C, Gely M, Santalla E. Physical properties of quinoa seeds. Biosystemic Engineering 2003;86(2):5965 .

35. www.biscuitfederation.org 2009. 